\title{
Blind reduction of mallet finger injuries
}

\author{
Michael SG Bell MD FRCSC FACS ${ }^{1}$, James G Jarvis MD FRCSC ${ }^{2}$ \\ ${ }^{I}$ Division of Plastic Surgery, Ottawa Hospital, Civic Campus, ${ }^{2}$ Division of Orthopaedic Surgery, \\ University of Ottawa, Children's Hospital of Eastern Ontario, Ottawa, Ontario
}

\begin{abstract}
MSG Bell, JG Jarvis. Blind reduction of mallet finger injuries. Can J Plast Surg 1999;7(3):115-116.
The present paper outlines a new, superior splinting technique that the authors have used over the past two years in approximately 30 cases of conservative treatment of mallet finger injuries. Its comfort has been uniformly accepted, and no complications with its use have been observed. The high rate of patient compliance is due to the minimal bulk of splint and its comfortable fit, which allows for less restricted finger movement. This splint is readily fabricated, and is an inexpensive and superior alternative to currently available manufactured devices.
\end{abstract}

Key Words: Mallet finger injury; Splinting

\section{Réduction à l'aveugle des blessures du doigt en maillet}

RÉSUMÉ : Le présent article décrit une technique nouvelle et supérieure de pose d'une attelle que les auteurs ont utilisé au cours des deux dernières années dans environ trente cas de traitement conservateur des blessures du doigt en maillet. Son confort a fait l'unanimité chez les patients, et aucune complication liée à son utilisation n'a été signalée. Le taux élevé de fidélité observé chez les patients est dû au volume minimal de l'attelle et au fait qu'elle s'ajuste aisément, permettant ainsi une plus grande liberté de mouvement du doigt. Cette attelle peut être fabriquée facilement et représente une alternative supérieure et peu coûteuse aux appareils actuellement disponibles sur le marché.

$\mathrm{N}$ onoperative treatment of mallet finger injury has been shown to be highly successful, and the indications for surgery are both rare and controversial (1-6). Good results have been reported, even when nonoperative treatment is delayed $(7,8)$. Poor results are seen too often when there is lack of compliance with nonoperative treatment (8). Pain due to skin ischemia and/or necrosis over the dorsum of the distal interphalangeal joint (DIP) is the usual cause of noncompliance and is a frequent complication when the DIP joint is held in hyperextension $(5,9)$. Numerous splinting techniques, both custom and commercial, have been devised to overcome these problems (10-14). Due to the significant and prolonged swelling often seen with tendonous injuries and the painful dorsal prominence associated with mallet fractures, these devices are often inadequate or poorly tolerated (12). These deficiencies have been overcome with a simple splint constructed from a 1" steel venetian blind.

Correspondence and reprints: Dr M Bell, Ottawa Hospital, Civic Campus, 1053 Carling Avenue, Ottawa Ontario KIY 4 E9. Telephone 613-739-5424, fax 613-739-7168, e-mail msgbell@cyberus.ca
The 1" steel slats from a venetian blind are simply trimmed to the appropriate length (Figure 1,2,3). The distal end should be rounded to follow the curve of the fingernail. If the edges flare out too much, they can irritate adjacent fingers. The concave surface is covered with a layer of 1 " microfoam tape for padding and to prevent any possible injury from the edge of the thin metal blind where it contacts the skin. Using cloth tape padding can result in rust developing on the blind, which is esthetically unappealing. The blind slat is highly flexible and can be moulded to curve by simply pinching it so that it adjusts to the circumference of different sized fingers. Because of the natural transverse curve, it is very resistant to bending in a longitudinal axis so that even the most seemingly thin piece of metal functions quite satisfactorily as a rigid splint. It also precludes hyperextension of the DIP joint, which is often associated with complications due to skin compression and irritation.

Coban tape (3M, Toronto) has been the preferred means of attaching this splint, but 1" 3M Microfoam Tape (3M, Toronto) may be substituted to cover the distal finger pulp and is preferred by people doing keyboard work. Tactile sensation is very good with this technique. First, tape the splint longitudinally with 1" $3 \mathrm{M}$ Microfoam Tape from the proxi- 


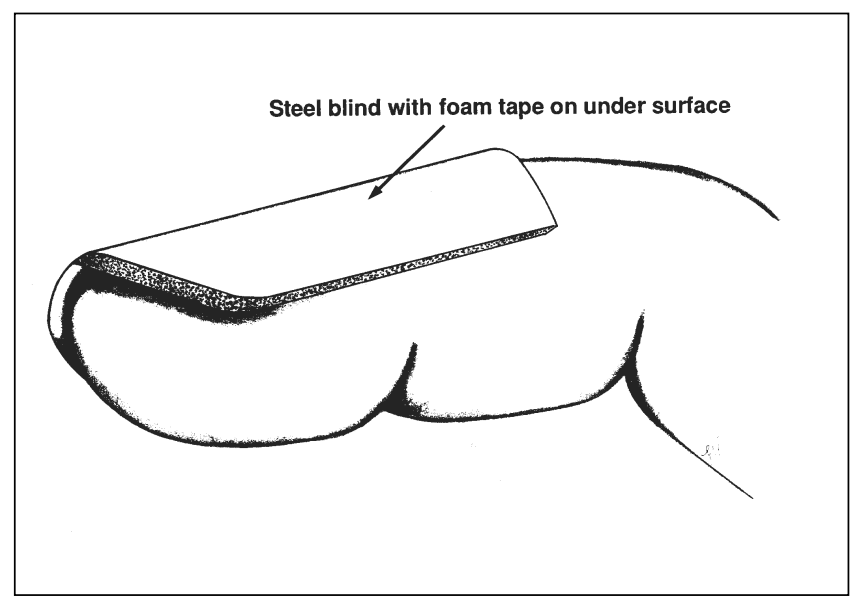

Figure 1) The blind with the foam tape applied to the digit

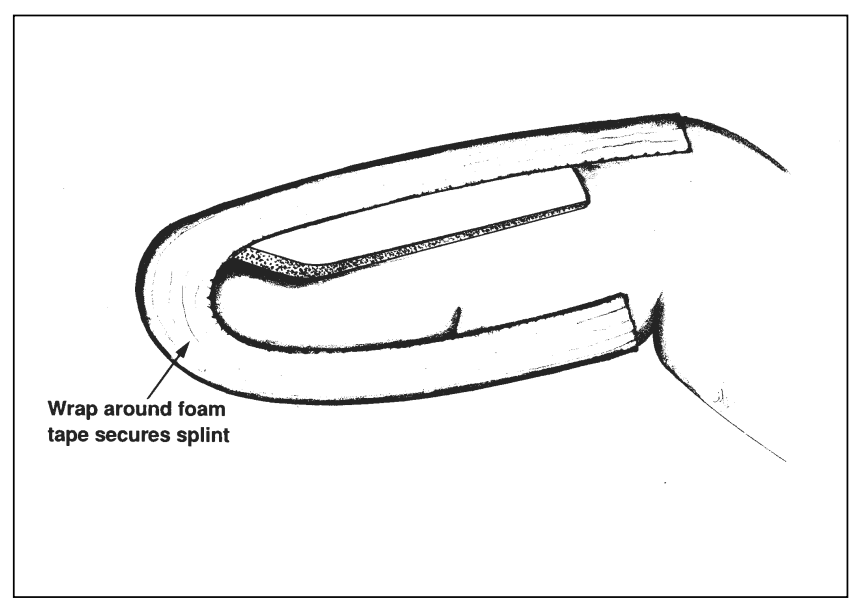

Figure 2) The blind secured with a longitudinal strip of 1" tape running proximal to the proximal interphalangeal joint level

mal interphalangeal (PIP) joint level on both the dorsal and volar surfaces. A proximal circumferential series of Coban tape wrapping then secures the proximal end of the splint, leaving the smallest area of finger pulp free for keyboard contact. It is best to have the splint extend no closer than $1 \mathrm{~cm}$ from the PIP joint to allow firm tape fixation and control.

The low bulk of this splint and the prevention against DIP hyperextension are the chief factors in improved compliance in patients with mallet finger injuries. This splint interferes less with finger function and allows better PIP motion than any other splint. It is an improvement over conventional commercial splints and is highly recommended.

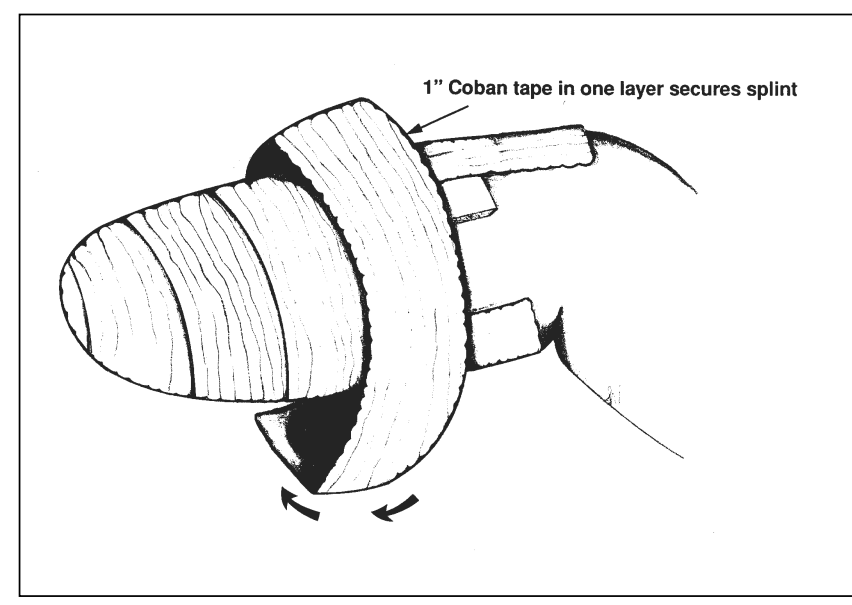

Figure 3) The final securing of the splint with circumferential 1" Coban tape (3M, Toronto). This can be replaced as required

\section{REFERENCES}

1. Crawford G. The molded polythene splint for mallet finger deformities. J Hand Surg [Am] 1984;9:231-7.

2. Foucher G, Binhamer P, Cange S, Lenoble E. Long-term results of splintage for mallet finger. Int Orthop 1996;20:129-31.

3. Newport M. Extensor tendon injuries of the hand. J Am Acad Orthop Surg 1997;5:59-66.

4. Okafor B, Mbubaegbu C, Munshi I, Williams DJ. Mallet deformity of the finger. Five-year follow-up of conservative treatment. J Bone Joint Surg Br 1997;79:544-7.

5. Stern PJ, Kastrup JJ. Complications and prognosis of treatment of mallet finger. J Hand Surg [Am] 1988;13:329-34.

6. Wehbe MA, Schneider LH. Mallet fractures. J Bone and Surg [Am] 1984;66:658-69.

7. Garberman SF, Diao E, Peimer CA. Mallet finger: results of early versus delayed closed treatment. J Hand Surg [Am] 1994;19:850-2.

8. Groth G, Wilder D, Young V. The impact of compliance on the rehabilitation of patients with mallet finger injuries. J Hand Ther 1994;7:21-4.

9. Rayan G, Mullins P. Skin necrosis complicating mallet finger splinting and vascularity of the distal interphalangeal joint overlying skin. J Hand Surg [Am] 1986;12:548-52.

10. Evans D, Weightman B. The pipflex splint for the treatment of mallet finger. J Hand Surg [Br] 1998;13:156-8.

11. Kinninmointh AW, Holburn F. A comparative controlled trial of a new perforated splint and a traditional splint in the treatment of mallet finger. J Hand Surg [Br] 1986;11:261-2.

12. Maitra A, Dorani B. The conservative treatment of mallet finger with a simple splint: a case report. Arch Emerg Med 1993;10:244-8.

13. Stack HG. A modified splint for mallet finger. J Hand Surg [Br] 1986;11:263.

14. Warren R, Norris S, Ferguson D. Mallet finger: a trial of two splints. J Hand Surg [Br] 1998;13:151-3. 